\title{
Can a repository site be safer than safe? - Criteria and methods for a safety-oriented comparison of repository sites
}

\author{
Martin Navarro $^{1, \mathrm{a}}$, Ingo Kock ${ }^{1, \mathrm{a}}$, Gerd Frieling ${ }^{1, \mathrm{a}}$, and Thomas Beuth ${ }^{1, \mathrm{a}}$ \\ ${ }^{1}$ Federal Office for the Safety of Nuclear Waste Management (BASE), Wegelystrasse 8, 10623 Berlin, Germany \\ a formerly at: GRS gGmbH, Schwertnergasse 1, 50667 Cologne, Germany
}

Correspondence: Martin Navarro (martin.navarro@bfe.bund.de)

Published: 10 November 2021

\begin{abstract}
In the course of the German site selection procedure, repository potential sites will be rejected if it becomes apparent that they will probably not meet the regulatory safety requirements (EndlSichAnfV). It is therefore likely that the remaining sites of the final selection phase (which is specified by paragraph 19 of the StandAG) will meet the safety requirements and are therefore capable of being approved. Under these circumstances, finding the site with the highest possible level of safety (as required by the StandAG) calls for a further differentiation of safety above the level of safety that is prescribed by the safety requirements. Based on this differentiation, operational criteria have to be developed for a safety-oriented comparison of repository sites and systems; however, finding suitable criteria is not a trivial task if the repository systems that are available for selection make use of different host rocks and therefore differ with respect to the internal structure and safety concept.

Between 2007 and 2010, criteria and associated evaluation methods for a safety-oriented comparison of approvable repository sites were developed by project 3607R02589 of the German Federal Ministry for the Environment, Nature Conservation and Nuclear Safety (BMU) within the joint project VerSi. The robustness of the repository system was proposed as a central criterion for site comparison. In the years to follow, criteria and evaluation methods were tested and refined by BfE/BMU projects $05504 / 2$ and 4719E03250, which finally showed a substantial need for further research and development. The presentation outlines the results of these three projects and discusses the questions that are still open.
\end{abstract}

Kurzfassung. Im Verlauf des deutschen Standortauswahlverfahrens werden potenzielle Endlagerstandorte ausgeschlossen, welche die gesetzlichen Sicherheitsanforderungen voraussichtlich nicht erfüllen (gesetzliche Sicherheitsanforderungen). Aus diesem Grund ist es wahrscheinlich, dass die in der finalen Auswahlphase (§ 19 StandAG) verbleibenden Standorte die Sicherheitsanforderungen erfüllen und daher genehmigungsfähig sind. Unter diesen Umständen ist zur Ermittlung des Standorts mit der bestmöglichen Sicherheit (siehe StandAG) eine weitere Differenzierung des Sicherheitsniveaus oberhalb des Sicherheitsniveaus der Sicherheitsanforderungen erforderlich. Auf Grundlage dieser Differenzierung müssen operationale Kriterien für einen sicherheitsorientierten Vergleich von Endlagerstandorten und -systemen entwickelt werden. Allerdings ist es keine leichte Aufgabe, geeignete Kriterien zu finden, wenn die Endlagersysteme, die zur Auswahl stehen, verschiedene Wirtsgesteine nutzen und sich daher im Hinblick auf die innere Struktur und das Sicherheitskonzept unterscheiden.

Zwischen 2007 und 2010 wurden im Projekt 3607R02589 des Bundesministeriums für Umwelt, Naturschutz und nukleare Sicherheit (BMU) innerhalb des Verbundprojektes VerSi Kriterien und damit verbundene Evaluationsmethoden für einen sicherheitsorientierten Vergleich von genehmigungsfähigen Endlagerstandorten entwickelt. Die Robustheit des Systems zur Endlagerung wurde als ein zentrales Kriterium für den Standortvergleich vorgeschlagen. In den folgenden Jahren wurden die Kriterien und Evaluationsmethoden durch die BfE/BMU-Projekte 05504/2 und 4719E03250 getestet und präzisiert, die schließlich einen erheblichen Bedarf 
an weiterer Forschung und Entwicklung aufzeigten. In der Präsentation werden die Ergebnisse dieser 3 Projekte skizziert und die noch offenen Fragen erörtert. 